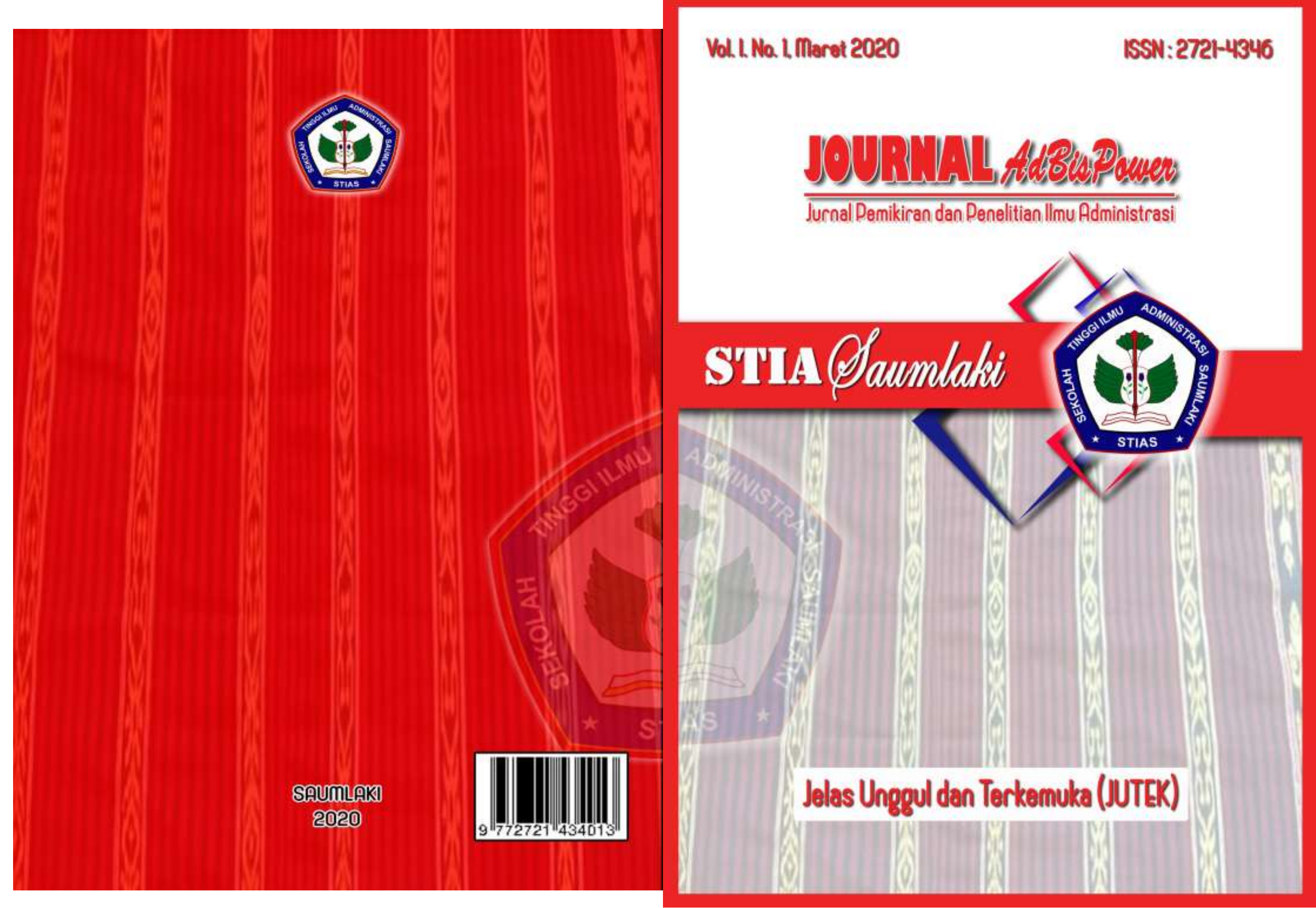




\title{
POTENSI KEPUNAHAN POHON TOREM DI PULAU YAMDENA KABUPATEN KEPULAUAN TANIMBAR
}

Oleh:

Johanis D.B. Malindir

(Dosen STIA Saumlaki)

\begin{abstract}
ABSTRAK
Pohon Torem merupakan salah satu tumbuhan endemik yang hidup di Pulau Yamdena. Masyarakat Maluku Tenggara Barat dalam sejarahnya telah cukup lama memanfaatkan kayu Torem sebagai bahan baku berbagai macam bangunan, mebel, maupun benda-benda kerajinan ukir. Kontribusi pohon torem bagi masyarakat Tanimbar tidak hanya sekedar dalam aspek ekonomi, namun juga dalam aspek sosial, religi, kesenian, dan kebudayaan itu sendiri. Keberadaan pohon torem didudukkan sebagai bagian penting bagi proses tumbuh-kembangnya kearifan lokal masyarakat Tanimbar. Dengan melihat pada potensi kearifan lokal, pemerintah terus tetap menjaga lestarinya hutan dan menjaga tanaman enedemik agar tidak punah.
\end{abstract}

Kata Kunci: Torem, Endemik, Kearifan Lokal, Tanimbar

\begin{abstract}
Torem Tree is one of the endemic plants that live on Yamdena Island. The people of West Southeast Maluku have historically used Torem wood as a raw material for various buildings, furniture, or carved crafts. The contribution of torem trees to the Tanimbar community is not only in the economic aspect, but also in the social, religious, artistic, and cultural aspects. The existence of torem trees is placed as an important part of the growth and development of the local wisdom of the Tanimbar people. By looking at the potential of local wisdom, the government continues to keep the forest sustainable and keep the enedemic plants from becoming extinct.
\end{abstract}

Keywords: Torem, Endemic, Local Wisdom, Tanimbar 


\section{PENDAHULUAN}

Hutan merupakan sumber daya alam yang sangat penting dan bermanfaat bagi hidup dan kehidupan baik secara langsung maupun tidak langsung. Manfaat langsung dari keberadaan hutan di antaranya adalah kayu, hasil hutan bukan kayu dan satwa. Sedangkan manfaat tidak langsungnya adalah berupa jasa lingkungan, baik sebagai pengatur tata air, fungsi estetika, maupun sebagai penyedia oksigen dan penyerap karbon.

Salah satu hasil hutan kayu di Indonesia yang memiliki nilai ekonomis adalah Pohon Torem (manilkara kanosiensis). Pohon torem merupakan salah satu pohon endemik yang hanya tumbuh di hutan Pulau Yamdena, Kabupaten Kepulauan Tanimbar, Maluku. Pohon torem termasuk dalam family Sapotaceae dan merupakan salah satu Genus Manilkara. Genus ini terdiri atas 65 jenis, di mana, 30 jenis terdapat di Amerika Serikat, 20 jenis di Afrika, dan 15 Jeni di Asia, Asutralia dan Pasifik. Di Malaysia terdapat 4 jenis yang tumbuh secara alami dan salah satunya jenisnya ditemukan di India, Sri Lanka, Burma, Thailand dan Indo-China. ${ }^{1}$

Lembaga Ilmu Pengetahuan Indonesia (LIPI) menyatakan pohon ini

\footnotetext{
${ }^{1}$ Soerianegara I dan RHMJ Lemmens, (Ed)., Plant Resources of South-East Asia, No.51(1): Timber Tress: (Porsea Bogor: Major Commercial Timbers, 1994).
}

sebagai endemik Maluku setelah dilakukan penelitian bertahap. Ciri-ciri fisiknya berbatang lurus dan besar, memiliki struktur keras berwarna cokelat-kuning hingga cokelat-merah, dan permukaan kayu licin. Bagian gubal berwarna coklat muda atau merah muda pucat, struktur kayu polos atau bergaris warna gelap dan terang, mempunyai kontur halus sampai sangat halus, arah serat lurus agak bergelombang sampai sedikit berpadu dan permukaan kayu licin mengkilap.

Menurut International Union for Conservation of Nature, pohon Torem masuk kategori nyaris punah. Karena kelangkaannya itu, Pusat Konservasi Tumbuhan Kebun Raya Lembaga Ilmu Pengetahuan Indonesia (LIPI) akhirnya menerbitkan sertifikasi bahwa pohon torem sebagai jenis pohon endemik, yang terancam kepunahannya di Pulau Yamdena sehingga Kodim 1507 Pattimura membudidayakan pohon torem untuk menjaga kelestariannya. ${ }^{2}$

Pohon torem yang hidup di hutan Yamdena merupakan hutan adat yang miliki oleh kesatuan masyarakat hukum adat, sebagaimana dalam Putusan Mahkamah Konstitusi (MK) No. 35 tahun 2002 menegaskan dua aspek penting bagi masyarakat hukum adat yaitu Pertama, menyatakan bahwa hutan adat bukan lagi

\footnotetext{
2 http://www.harnas.co/2017/11/15/sejarah- barubagi-pohon-torem, (10 Juli 2018).
} 
hutan Negara, dalam putusan MK menyebutkan bahwa hutan adat adalah hutan yang berada dalam wilayah adat milik masyarakat adat. Putusan MK 35 merupakan sebuah terobosan hukum yang dilakukan oleh hakim MK untuk memberikan pengakuan masyarakat adat dan wilayah adatnya karena putusan ini semakin menegaskan bahwa masyarakat hukum adat adalah subjek hukum dan pemilik hak atas wilayah adat. Kedua, Mahkamah Konstitusi telah mengabulkan permohonan pencabutna pasal 67 Undangundang (UU) Kehutanan kembali menegaskan pengakuan bersyarat bagi masyarakat adat. Mahkamah konstitusi berpandangan pengakuan keberadaan masyarakat adat melalui perda masih relevan dan tidak inkonstitusional sepanjang belum adanya undang-undang masyarakat adat. ${ }^{3}$

Ancaman kepunahan pohon torem di Hutan Yamdena yang merupakan hak masyarakat hokum adat karena tiga hal; pertama, system berkebun Orang Tanimbar yang masih sangat tradisional, yaitu berladang dan berpindah tempat yang mengakibatkan kerusakan hutan dan ancaman

\footnotetext{
3 Arman, Muhammad (2016). "Legislasi Daerah Masyarakat Adat Pasca Putusan MK. 35/PUUX/2012". Makalah pada pertemuan Simposium Masyarakat Adat II Gerakan Masyaraakt Adat dan Pembaharuan Hukum Peringatan 2 Tahun Putusan Mahkamah Konstitusi No. 35/PUU-X/2012. Universitas Pancasila, hal 4.
}

kepunahan pohon torem. Kedua, izin pengelolaan hutan desa oleh kementerian kehutanan dan lingkungan hidup kepada masyarakat desa di Tanimbar yang tidak memiliki pengetahuan akan pelestarian hutan, sehingga terjadi deforsetasi dan kepunahan pohon torem. Ketiga, Hak Pengelolaan Hutan (HPH) Yamdena oleh PT. Karya Jaya Berdikari. Kehadiran perusahaan tersebut dalam mengelola hutan Yamdena, berpotensi mengancam kepunahan pohon torem di Tanimbar.

Berdasarkan permasalahan yang dirumuskan di atas, maka peneliti tertarik untuk melakukan penelitian ini yang akan difokuskan pada Potensi Kepunahan Pohon Torem di Hutan Yamdena, Kabupaten Kepulauan Tanimbar, Provinsi Maluku.

\section{LANDASAN TEORI}

Pada bagian ini akan mendeskripsikan konsep yang relevan dalam memotret fenomena yang diteliti, yakni potensi kepunahan pohon torem di hutan Yamdena Kepulauan Tanimbar. Konsep hak masyarakat hukum adat digunakan untuk memotret hak masyarakat Tanimbar akan Hutan Yamdena. Konsep perampasan hutan untuk memotret investasi perusahaan, 
dan konsep deforstasi untuk menjelaskan kerusakan hutan.

\section{a. Hak Masyarakat Hukum Adat}

\section{Undang-Undang Dasar Negara}

Republik Indonesia Tahun 1945 pada

Pasal 18B ayat (2) telah menjamin keberadaan masyarakat hukum adat dengan memberikan pengakuan bersyarat. Pada penelitian ini istilah masyarakat hukum adat mengutip pendapat ahli dari Hazairin yang mengatakan bahwa masyarakat hukum adat adalah kesatuankesatuan masyarakat yang mempunyai kelengkapankelengkapan untuk sanggup berdiri sendiri yang mempunyai kesatuan hukum, kesatuan penguasa, dan kesatuan lingkungan hidup berdasarkan hak bersama atas tanah dan air bagi semua anggotanya. $^{4}$

Keberadaan masyarakat hukum adat tidak saja telah mendapatkan perlindungan secara yuridis konstitusional sebagaimana diatur dalam Pasal 18B ayat (2), melainkan perlindungannya lebih kuat lagi karena dipertegas dalam Pasal 28I tentang HAM. Di satu pihak, secara yuridis, otonomi desa yang bersifat otonom asli diakui oleh negara. Pasal 18B ayat (2) UUD 1945 menyatakan secara jelas "Negara mengakui dan menghormati

4 Simarmata. 2006, sebagaimana dikutip Safrin Salam, Perlindungan Hukum Masyarakat Hukum Adat atas Hutan Adat, Jurnal Hukum Novelty, Vol.7 No.2 Agustus 2016, hal. 210. kesatuan-kesatuan masyarakat hukum adat beserta hak-hak tradisionalnya sepanjang masih hidup dan sesuai dengan perkembangan masyarakat dan prinsip Negara Kesatuan Republik Indonesia yang diatur dalam undang-undang". 5

\section{b. Perampasan Hutan-Tanah}

Kata "perampasan" itu sendiri berfokus pada cara meraih sumber daya tersebut yang menciptakan dinamika kepemilikan, yaitu dengan merampas tanah, air, hutan atau sumber daya publik lainnya, yang kemudian terkonsentrasi, mengalami privatisasi, dan transaksi yang berpusat pada kepemilikan korporasi, baik dibeli atau disewa dan berikutnya turut mendorong adanya transformasi rezim tenaga kerja agrarian. Kemudian, Borras Jr, dkk, mengajukan definisi perampasan tanah sebagai berikut:

"Perampasan tanah adalah upaya untuk memperoleh kontrol atas tanah dalam skala luas atau juga sumberdaya alam yang lain melalui berbagai konteks dan bentuk yang mencakup modal dalam jumlah besar yang seringkali mengubah orientasi penggunaan sumberdaya ke dalam sifat-sifatnya yang ekstraktif, baik untuk tujuan

\footnotetext{
${ }^{5}$ Jawahir Thontowi, Perlindungan dan Pengakuan Masyarakat Adat dan Tantangannya dalam Hukum Indonesia, Jurnal Hukum IUS QUIA IUSTUM NO. 1 VOL. 20 JANUARI 2013, hal 28.
} 
internasional atau domestik, dan coklat. Pertumbuhan ekonomi ini sebagai respons terhadap dicapai tanpa memperhatikan pengelolaan konvergensi pangan, sumberdaya dari kapital yang baru.",6 hutan secara berkelanjutan atau hak-hak penduduk lokal.

\section{c. Konsep Deforestasi}

Deforestasi di Indonesia sebagian besar merupakan akibat dari suatu sistem politik dan ekonomi yang korup, yang menganggap sumber daya alam, khususnya hutan, sebagai sumber pendapatan yang bisa dieksploitasi untuk kepentingan politik dan keuntungan pribadi. Pertumbuhan industri pengolahan kayu dan perkebunan di Indonesia terbukti sangat menguntungkan selama bertahuntahun, dan keuntungannya digunakan oleh rejim Soeharto sebagai alat untuk memberikan penghargaan dan mengontrol teman-teman, keluarga dan mitra potensialnya. Selama lebih dari 30 tahun terakhir, negara ini secara dramatis meningkatkan produksi hasil hutan dan hasil perkebunan yang ditanam di lahan yang sebelumnya berupa hutan. Dewasa ini Indonesia adalah produsen utama kayu bulat, kayu gergajian, kayu lapis, pulp dan kertas, disamping beberapa hasil perkebunan, misalnya kelapa sawit, karet

\footnotetext{
${ }^{6}$ DICKY DWI ANANTA, 2014. Politik Oligarki dan Perampasan Tanah di Indonesia: Kasus Perampasan Tanah di Kabupaten Karawang, Jakarta: Institut Kajian Krisis dan Strategi Pembangunan Alternatif (Inskripena), hal. 102103.
}

\section{METODE PENELITIAN}

Penelitian ini menggunakan pendekatan deskriptif kualitatif, dan jenis penelitian yang digunakan adalah kepustakaan (library research), yaitu mengumpulkan data atau karya tulis ilmiah yang berkaitan dengan obyek penelitian atau pengumulan data yang bersifat kepustakaan. Atau telaah yang dilaksanakan untuk memecahkan suatu masalah yang pada dasarnya tertumpu pada penelaahan kritis dan mendalam terhadap bahan-bahan pustaka yang relevan.

Penelitian kepustakaan ini memiliki beberapa ciri khusus, antara lain; pertama, penelitian ini berhadapan langsung dengan teks atau data angka, bukan dengan lapangan atau saksi mata (eyewitness), berupa kejadian, orang atau benda-benda lain. Kedua, data bersifat siap pakai (readymade), artinya peneliti tidak pergi kemana-mana, kecuali hanya berhadapan langsung dengan sumber yang sudah ada di perpustakaan. Ketiga, data diperpustakaan umumnya adalah sumber data sekunder, dalam arti bahwa peneliti memperoleh data dari tangan kedua bukan asli dari tangan pertama dilapangan. 
Keempat, kondisi data di perpustakaan tidak dibagi oleh ruang dan waktu. ${ }^{7}$

\section{PEMBAHASAN}

\section{A. Dasar Hukum dan Sistem Berladang Orang Tanimbar 1. Dasar Hukum}

Untuk memberikan perlinduangn terhadap flora dan fauna di Indonesia, pemerintah telah mengeluarkan beberapa peraturan perundang-undangan yang satu dengan lainnya saling berkaitan, diantaranya adalah:

1. Undang-Undang Nomor 5 Tahun 1990 tentang Konservasi Sumber Daya Alam Hayati dan Ekosistemnya. Dalam sejarahnya, terbitnya UndangUndang Nomor 5 Tahun 1990 tentang Konservasi Sumber Daya Alam Hayati (UUKH) tidak lepas dari peran Indonesia sebagai negara mega biodiversity yang telah meratifikasi Convention on International Trade of Endangered Species of Wild Fauna and Flora (CITES) melalui Keputusan Presiden (Keppres) Nomor 43 Tahun 1978 tentang Pengesahan CITES. CITES merupakan merupakan perjanjian internasional (multilateral) yang terkait dengan perlindungan dan perdagangan internasional spesies satwa dan tumbuhan liar yang terancam punah. Konvensi yang ditandatangani 3 Maret 1973 juga

\footnotetext{
${ }^{7}$ Mestika Zed, Metode Penelitian Kepustakaan (Jakarta: Yayasan Obor Indonesia, 2004), hal 18.
}

dikenal dengan Konversi Washington, dan Indonesia terdaftar sebagai negara ke 48 peserta CITES. ${ }^{8}$

Pemerintah membutuhkan waktu yang cukup lama, 12 tahun untuk membuat peraturan perundangundangan pelaksana atas proses ratifikasi CITES. Peraturan Perundang-undangan tersebut adalah Undang-Undang Nomor 5 Tahun 1990 tentang Konservasi Sumber Daya Alam Hayati (UUKH) yang menjadi dasar hukum yang dipakai dalam perlindungan satwa dan fauna liar tertuang dalam tiap klausula yang meliputi pengambilan/penangkapan Tumbuhan dan Satwa Liar (TSL) baik komersial maupun non komersial dari habitat alam hanya dapat dilakukan di luar kawasan pelestarian alam (Taman Nasional, Taman Wisata Alam, Taman Hutan Raya), kawasan suaka alam (Cagar Alam, Suaka Marga Satwa) atau taman buru, yang semua tercakup dalam Bab III yang terdiri dari Pasal 11 sampai dengan Pasal 13 UUKH.

Pemerintah juga membutuhkan waktu Sembilan tahun untuk mensahkan Peraturan Pelaksana dari

\footnotetext{
${ }^{8}$ Indonesia, Keputusan Presiden No. 43 Tahun 1978 tentang Pengesahan Convention on International Trade of Endangered Species of Wild Fauna and Flora (CITES), dalam Andri Santosa (ed), Konservasi Indonesia: Sebuah Potret Pengelolaan dan Kebijakan, Cetakan ke-1, (Jakarta: Pokja Kebijakan Konservasi, USAID dan ESP, 2008), 35.
} 
UUKH dalam melindungi flora maupun fauna yang dilindungi. Peraturan pelaksana tersebut antara lain Peraturan Pemerintah Nomor 7 Tahun 1999 tentang Pengawetan Jenis Tumbuhan ${ }^{9}$ dan Satwa, dan Peraturan Pemerintah Nomor 8 Tahun 1999 tentang Pemanfaatan Jenis Tumbuhan dan Satwa Liar. ${ }^{10}$

\section{Untuk} memberikan perlindungan terhadap flora maupun fauna langka, maka diperlukan konservasi. Pengertian konservasi sumber daya alam hayati menurut pasal 1 ayat (2) UUKH, dirumuskan bahwa "pengelolalaan sumber daya alam hayati yang pemanfaatanya

\footnotetext{
${ }^{9}$ Menurut PP ini adalah upaya untuk menjaga agar keanekaragaman jenis tumbuhan dan satwa beserta ekosistemnya baik di dalam atau di luar habitatnya tidak pnah. PP ini mengatur mengenai upaya pengawetan, penerapan jenis tumbuhan dan satwa, pengelolaan jenis tumbuhan dan satwa serta habitatnya, lembaga konservasi pengiriman atau pengangkutan tumbuhan dan satwa yang dilindungi, satwa yang membahayakan kehidupan manusia dan pengawasan serta pengendalian.

${ }^{10}$ Berdasarkan PP ini, pemanfaatan jenis adalah penggunaan sumber daya alam baik tumbuhan maupun satwa liar atau bagian-bagannya serta hasil dari padanya dalam bentuk pengkajian, penelitian dan pengembangan, penangkaran pperburuan, perdagangan, peragaan, budi daya tanaman obat-obatan. PP ini mengatur yang terkait dengan pemanfaatan satwa sebagai berikut: (1) Pengkajian, penilaian dan pengembangan, (2) penangkaran, (3) perdagangan, (4) peragaan jenis tumbuhan dan satwa liar dapat berupa koleksi hidup/koleksi mati termasuk bagian-bagiannya, (5) pertukaran jenis tumbuhan dan satwa liar dilakukan dengan tujuan untuk mempertahankan atau meningkatkan populasi, memperkaya keanekaragaman jenis, penelitian dan ilmu pengetahuan, (6) budi daya tanaman obat-obatan, (7) pemeliharaan untuk kesenangan, (8) pengiriman atau pengangkutan tumbuhan dan satwa liar, serta (10) daftar klasifikasi dan kuota.
}

dilakukan secara bijaksana untuk menjamin kesinambungan persediannya dengan tetap memelihara dan meningkatkan kualitas keanekaragaman dan nilainya". Dengan demikian konservasi dalam undang-undang ini mencakup pengelolaan sumber alam hayati, yang termasuk didalamnya hutan. Sasaran konservasi yang ingin dicapai menurut UUKH, yaitu:

a. Menjamin terpeliharanya proses ekologis yang menunjang sistem penyangga kehidupan bagi kelangsungan pembangunan dan kesejahteraan manusia (perlindungan sistem penyangga kehidupan);

b. Menjamin terpeliharanya keanekaragaman sumber genetik dan tipe-tipe ekosistemnya sehingga mampu menunjang pembangunan, ilmu pengetahuan, dan teknologi yang memungkinkan pemenuhan kebutuhan manusia yang menggunakan sumber daya alam hayati bagi kesejahteraan (pengawetan sumber plasma nutfah);

c. Mengendalikan cara-cara pemanfaatan sumber daya alam hayati sehingga terjamin kelestariannya. Akibat sampingan 
ilmu pengetahuan dan teknologi yang kurang bijaksana, belum harmonisnya penggunaan dan peruntukan tanah serta belum berhasilnya sasaran konservasi secara optimal, baik di darat maupun di perairan dapat mengakibatkan timbulnya gejala erosi genetik, polusi, dan penurunan potensi sumber daya alam hayati (pemanfaatan secara lestari).

2. Undang-Undang Nomor 32 Tahun 2009 tentang Perlindungan dan Pengelolaan Lingkungan Hidup (UUPLH) Bahwasanya tidak semua flora maupun fauna dapat hidup di semua tempat kecuali pada habitatnya masing-masing. Dalam UUPLH juga terdapat istilah ekoregion, yaitu geografis yang memiliki kesamaan ciri iklim, tanah, air, flora, dan fauna asli, serta pola interaksi manusia dengan alam yang menggambarkan integritas sistem alam dan lingkungan hidup. ${ }^{11}$ Peraturan UUPLH ini memberikan daya dukung yang mengatur perlindungan dan pengelolaan lingkungan hidup, sehingga flora dan fauna liar yang merupakan bagian dari ekosistem lingkungan hidup

\footnotetext{
${ }^{11}$ Undang-Undang Republik Indonesia Nomor 32 Tahun 2009 tentang Perlindungan dan Pengelolaan Lingkungan Hidup, Pasal 1 Ayat (29).
}

mendapatkan regulasi yang kuat dalam kelestariannya.

3. Undang-Undang Nomor 41 Tahun 1999 tentang Kehutanan

Aspek lingkungan hidup ini penting didasarkan pada upaya pelestarian dan perlindungan terhadap kekayaan alam sebagai hak bersama untuk dinikmati dan wajib dijaga agar dapat terus memberi faedah dalam kesehariannya. Tidak terlepas dari itu, bidang kehutanan sebagai salah satu bagian dari Lingkungan Hidup media spesies flora, merupakan karunia Tuhan Yang Maha Esa dan salah satu kekayaan alam yang sangat penting bagi manusia. Hal ini diakibatkan banyaknya manfaat yang sdapat diambil dari hutan dalam mengamankan flora maupun fauna dengan itu ada kewajiban menjaga keselarasan, keseimbangan serta keharmonisan jagad raya serta dengan memperhatikan kehidupan keberlanjutan dimasa yang akan datang. Dengan banyak manfaat tersebut, hutan pun menjadi sangat idola bagi pemanfaatan sumber daya kekayaan alam.

Faktor ini pun menjadi alasan utama eksploitasi hutan. Padahal jika dicerna keberadaan hutan tidak hanya dapat dilihat dari sisi ekonomis saja tetapi juga dari social budaya, dimana hutan 
sebagai tempat tinggal berbagai macam mahluk hidup manusia,binatang, dan tumbuhan serta dari sisi kesehatan sebagai paru-paru dunia, senjata ampuh bagi "Global Warming" serta banyak manfaat lain. Dalam peraturan kehutanan ini diatur aspek Pidana didalam yang dapar membatasi dan mengatur penerapan penjatuhan sanksi bagi siapa saja yang melakukan pengerusakan dan pencemaran hutan. Dengan adanya aspek hukum pidana dalam bidang kehutanan ini setidaknya dapat meminimalisir adanya kerugian tersebut.

4. Peraturan Pemerintah No. 28 Tahun 2011, tentang Pengelolaan Kawasan Suaka Alam dan Kawasan Pelestarian Alam. Peraturan pemerintah ini juga berkontribusi dalam memperkuat landasan hukum bagi perlindungan satwa dan fauna liar dengan cara mengatur dalam pengelolaan kawasan suaka alam, pengelolaan pelestarian alam, Suaka Margasatwa, Taman Wisata Alam, Satwa liar, Peran serta masyarakat, Badan usaha adalah badan usaha milik negara, badan usaha milik daerah, badan usaha milik swasta dan koperasi yang terkait dengan pelestarian alam.

5. Peraturan Pemerintah Nomor 8 Tahun 1999 tentang Pemanfaatan Jenis
Tumbuhan dan Satwa Liar. Dalam peraturan pemerintah ini mengatur pengkajian, penelitian, pengembangan, penangkapan, perburuan, perdagangan, peragaan pertukaran, budidaya, pengangkutan dan sanksi administratif terhadap perburuan satwa buru

6. Peraturan Pemerintah No. 7 Tahun 1999 tentang Pengawetan Jenis Tumbuhan dan Satwa. Peraturan pemerintah ini mengatur mengenai pengawetan, pengelolaan, budidaya satwa dan fauna liar.

7. Peraturan Menteri Kehutanan No: P. 57/Menhut-II/2008 Tentang Arahan Strategis Konservasi Spesies Nasional tahun 2008 - 2018. Peraturan menteri ini memberikan delegasi untuk membentuk dan atau menunjuk institusi baik dari unsur pemerintahan ataupun swadaya yang mendukung terhadap upaya perlindungan satwa dan fauna liar.

Berdasarkan Peraturan Menteri Kehutanan No : P. 57/Menhut- II/2008 Tentang Arahan Strategis Konservasi Spesies Nasional tahun 2008 - 2018 Sejauh ini sebanyak 13 lembaga yang terkait dalam isu konservasi telah diidentifikasi. Lembaga-lembaga tersebut adalah:
a. Kementrian
Kehutanan, khususnya Direktorat Jenderal 
PHKA sebagai

otoritas

pengelolaan

(Management

Authority) yang membawahi

Balai Konservasi Sumber Daya

Alam (BKSD) yang merupakan institusi dari pelaksanaan tugas dari Direktorat Jenderal Perlindungan Hutan dan Konservasi Alam (PHKA) Departemen Kehutanan mempunyai tugas antara lain Inventarisasi dan identifikasi potensi flora fauna; Patroli rutin; Operasi pengamanan hutan fungsianal dan gabungan; Pengembangan kerjasama dan kemitraan dengan LSM dan instansi terkait; Perlindungan pengamanan kawasan; Penanganan kasus; Fasilitasi penelitian dan pendidikan; Pembinaan generasi muda pecinta alam; Pembinaan daerah penyangga; dan Pengawasan peredaran lalulintas flora fauna.

b. Kementrian Kelautan dan Perikanan Penyusunan, dan pelaksanaan rencana kerja dan anggaran Dinas Kelautan dan Pertanian yang bertugas dalam perumusan kebijakan regulasi maupun sampai dengan teknis operasional yang meliputi mekanisme produksi, pengelolaan, pengembangan pengetahuan dan keterampilan sumber daya manusia, Pengendalian dan pengawasan di sektor kelautan dan pertanian.

c. Kementerian Negara Lingkungan Hidup berdasarkan Permen Lingkungan Hidup No. 1 Tahun 2012 tentang Program Menuju Indonesia Hijau Kementrian Lingkungan Hidup bertugas menjaga kelestarian fungsi lingkungan hidup; mendorong pemanfaatan tutupan vegetasi secara bijaksana; meningkatkan resapan gas rumah kaca dalam rangka; dan mitigasi perubahan iklim.

d. Kementrian Pertanian Pusat Perlindungan Varietas Tanaman dan Perizinan Pertanian mempunyai tugas melaksanakan pengelolaan perlindungan varietas tanaman serta pelayanan perizinan dan rekomendasi teknis pertanian, dan berfungsi melaksanakan perumusan rencana, program dan anggaran, serta kerjasama; pemberian pelayanan permohonan hak dan pengujian perlindungan varietas tanaman, serta pendaftaran varietas dan sumber daya genetik tanaman; 
penerimaan, analisis, fasilitasi proses teknis penolakan atau pemberian izin, rekomendasi teknis, dan pendaftaran di bidang pertanian; pelayanan penamaan, pemberian, penolakan permohonan, pembatalan hak, serta pelayanan permohonan banding, konsultasi, pertimbangan hukum perlindungan varietas tanaman; dan Pelaksanaan urusan tata usaha dan rumah tangga Pusat Perlindungan Varietas dan Perizinan Pertanian

e. Lembaga Ilmu Pengetahuan Indonesia sebagai otoritas ilmiah (Scientific Authority)

f. Pemerintah Daerah (kabupaten/ kota dan provinsi)

g. Lembaga Swadaya Masyarakat di bidang konservasi

h. Lembaga-lembaga penelitian

i. Lembaga pendidikan tinggi (universitas)

j. Konsultan AMDAL dan lembaga penilai (sertifikasi hutan, dan lainnya)

k. Sektor swasta secara umum.

1. Lembaga lain yang juga menangani hal-hal yang terkait dengan konservasi.

\section{Sistem Berladang Orang Tanimbar}

Konsep pertanian berkelanjutan haruslah menjamin kualitas lahan kita tetap produktif dengan menerapkan upaya konservasi dan rehabilitasi terhadap degradasi. Kebijakan pembangunan pertanian dewasa ini lebih banyak terfokus kepada usaha yang mendatangkan keuntungan ekonomi jangka pendek dan mengabaikan multifungsi yang berorientasi pada keuntungan jangka panjang dan keberlanjutan (sustainabilitas) sistem usaha tani. Pertanian berkelanjutan, suatu bentuk yang memang harus dikembangkan jika kita ingin menjadi pewaris yang baik yang tidak semata memikirkan kebutuhan sendiri tetapi berpandangan visioner ke depan.

$$
\text { Pembangunan pertanian }
$$
berkelanjutan menyiratkan perlunya pemenuhan kebutuhan (aspek ekonomi), keadilan antar generasi (aspek sosial) dan pelestarian daya dukung lingkungan/lahan (aspek lingkungan). Sehingga harus ada keselarasan antara pemenuhan kebutuhan dan pelestarian sumberdaya lahannya. Pembangunan pertanian yang dilaksanakan masa lalu belumlah sepenuhnya menggunakan tiga aspek pembangunan yang berkelanjutan secara seimbang, sehingga masih banyak keluarga yang tergolong miskin, dan 
terjadi degradasi lahan sehingga mengganggu keberlanjutan pembangunan ekonomi dan social. ${ }^{12}$

Masyarakat Tanimbar adalah kumpulan masyarakat adat yang dalam keseharian hidupnya selalu berpegang teguh pada sistem budaya lokal yang berlaku dimana perilaku hidup mereka terus-menerus ditunjukan, dan selalu dilandaskan pada budaya yang dianut (Alaslan, 2021:6). Sistem berladang yang berpindah tempat menjadi budaya Orang Tanimbar dalam berkebun.

Berladang dengan berpindahpindah tempat mengakibatkan kerusakan terhadap lingkungan dan juga fauna endemik seperti pohon torem. Berpindah tempat karena system perkebunan yang berbasis kultur. Yang dimaksudkan dengan system perkebunan berbasis kultural yakni adanya tahapan yang harus dilalui oleh petani, yang dimulai dengan pembukaan lahan baru hingga panen hasil kebun.

\section{Hak Pengelolaan Hutan}

Pulau Yamdena merupakan bagian dari gugusan Kepulauan Tanimbar, Provinsi Maluku. Pulau ini sebagai sentra administrasi pemerintahan dan perekonomian di Kabupaten Kepulauan

\footnotetext{
${ }^{12}$ Suntoro Wongso Atmojo, Degradasi Lahan \& Ancaman bagi Pertanian, SOLO POS, Selasa pon, 7 Nopember 2006, hal 7.
}

Tanimbar. Pulau Yamdena termasuk dalam 2 wilayah administrasi pemerintahan yaitu Kecamatan Tanimbar Utara dengan ibukota kecamatannya Larat yang terletak di Pulau Larat dan Kecamatan Tanimbar Selatan dengan ibukota kecamatannya Saumlaki di Pulau Yamdena. Kecamatan Tanimbar Utara terdiri atas 36 buah pulau dan hanya 8 buah pulau yang berpenghuni berhubung keadaan tanah yang tidak dapat dijadikan lahan pertanian/ perkebunan. Kecamatan Tanimbar Selatan meliputi 4 buah pulau dengan 32 buah desa.

Salah satu wilayah yang mempunyai potensi penghasil kayu hutan tropis adalah Pulau Yamdena. Pulau yang mempunyai luas 325.725 ha ini telah dilakukan eksploitasi oleh PT. Alam Nusa Segar dengan SK Menteri Kehutanan No. 215/Kpts-II/1991 tanggal 23 April 1991 dengan luas 164.000 Ha. Kemudian diaddendum dengan SK Menteri Kehutanan No. 1107/Kpts-II/1992 tanggal 12 Desember 1992 dan berganti nama PT. Yamdena Hutani Lestari dengan luas 160.725 Ha. Dikarenakan perusahaan Yamdena Hutani Lestari melakukan eksploitasi berlebih maka perusahaan ini dicabut oleh Menteri Kehutanan dengan SK pencabutan No. 200/Menhut-II/2007 tanggal 16 Mei 2007.

Keberadaan isu degradasi hutan di Pulau Yamdena telah berkembang dari 
kalangan masyarakat setempat, LSM, pemerintah daerah maupun instansi internasional (Uni Eropa, CIRAD Perancis dan Bird Life). Pada saat ini, isu yang diangkat terhadap degradasi hutan di wilayah ini mengarahkan kesalahan kepada pihak investor yang mengeksploitasi hutan berlebih dan juga pemerintah yang telah membagi tata ruang wilayah yang kurang tepat. Pada awalnya penetapan areal yang dapat dieksploitasi berpedoman pada Peta Tata Guna Hutan Kesepakatan (TGHK) yang diterbitkan sekitar tahun 1980-an.

Pada Tahun 2003 pemerintah daerah menetapkan Rencana Tata Ruang Wilayah (RTRW) Kabupaten Kepulauan Tanimbar yang ditetapkan melalui Perda No.10 Tahun 2003 tentang Rencana Tata Ruang Wilayah Kabupaten Kepulauan Tanimbar, yang merupakan adopsi dari Peta Kawasan Hutan dan Perairan Tahun 1999 (SK Menteri Kehutanan No 415/Kpts-II/1999). Dengan desakan dan masukan berbagai kalangan maka Bupati Maluku Tenggara Barat mengeluarkan Surat Keputusan No.522- 071-Tahun 2006 tentang Usulan Perubahan Status dan Fungsi Kawasan Hutan Pulau Yamdena Kabupaten Kepulauan Tanimbar. Kemudian disusul Surat Dukungan DPRD Kabupaten MTB no.170/127/RDPRMTB/IV/2006 tentang Dukungan DPRD Kabupaten MTB terhadap Permohonan
Penilaian hingga Pengesahan Usulan Perubahan Status Lahan dan Fungsi Kawan Hutan Pulau Yamdena. ${ }^{13}$

Keberadaan hutan di Pulau Yamdena merupakan aset yang perlu dimanfaatkan untuk memenuhi kebutuhan masyarakat akan kayu dan pemenuhan pendapatan daerah setempat. Pengelolaan hutan harus dijalankan dengan kaedah profesional dengan pertimbangan kelestarian hasil maupun kelestarian lingkungan. Dengan pertimbangan hal tersebut maka pemerintah membuka peluang lagi bagi investor untuk mengeksploitasi hutan Yamdena.

Pada Tahun 2007 Gubernur Maluku memberi rekomendasi (No.522.11- 26) kepada PT.Karya Jaya Berdikari (KJB) memanfaatkan hasil hutan kayu di wilayah Pulau Yamdena, begitu juga untuk Bupati Maluku Tenggara Barat lewat Surat Rekomendasi Bupati No.522/093/Rek/2007 sedangkan Surat Ijin Usaha Pemanfaatan Hasil Hutan Kayu dari Menteri Kehutanan dikeluarkan pada tanggal 19 Maret 2009 dengan SK.117/Menhut-II/2009. Namun demikian setelah semua perijinan diterbitkan timbulah penolakan dari berbagai kalangan bagi investor yang akan mengelola hutan di Pulau Yamdena.

\footnotetext{
13 Kajian Degradasi Hutan Di Pulau Yamdena, Maluku, 2009, http://storage.jakstik.ac.id/ProdukHukum/kehutanan/Kajian_Degra dasi_Yamdena_1998_2008.pdf,
} 
Seperti alasan-alasan sebelumnya bahwa penolakan ini mengangkat isu degradasi hutan di Pulau Yamdena.

Berbagai bentuk ketidakadilan, termasuk ketidakadilan agraria, lingkungan, gender, dan sosial, yang menimpa masyarakat adat sebagai akibat dari penguasaan negara terhadap hutan mendorong munculnya beragam bentuk perlawanan yang kemudian berkembang menjadi gerakan-gerakan sosial. Polanyi (1957) menyebut gerakan ini sebagai "gerakan tandingan" (countermovement), sebagai upaya melindungi tanah, tenaga kerja, dan sumber-sumber kehidupan dari proses komodifikasi. Menurut Polanyi (1957), gerakan-gerakan tandingan terbentuk karena masyarakat mengenali risiko kehancuran dan menyusun langkahlangkah perlindungan untuk membangun kembali kehidupannya. Gerakan-gerakan tandingan di Eropa dan Amerika pada abad ke-19 yang diamati Polanyi (1957) memiliki komponen multikelas dan di dalamnya terdapat peran para kritikus. Polanyi juga mengamati gerakan-gerakan yang merupakan koalisi strategis di antara berbagai aktor, termasuk di dalamnya warga yang kritis, para ahli yang memiliki kepedulian, dan anggota partai-partai politik berhaluan kiri (Polanyi 1957). Polanyi tidak melakukan kajian tentang bagaimana dan kapan gerakan-gerakan tandingan mulai terbentuk (Hart 2002).

\section{KESIMPULAN}

Dari uraian pembahasan di atas, maka dapat disimpulakn sebagai berikut:

1. Bahwa berdasarkan peraturan perundang undangan yang mengatur tentang kehutanan dan lingkungan hidup, menjamin akan hak masyarakat hukum adat Tanimbar. Artinya bahwa masyarakat memiliki hak untuk mengelola hutan-tanah dalam wilayahnya, tetapi masyarakat menggunakan kebebebasan pengelolaan tanpa mempertimbangkan dampak ekologis dan kelestarian pohon torem di Tanimbar.

2. Masyarakat Tanimbar memiliki hak ulayat atas hutan-lahan, sebagaimana diamanatkan dalam peraturan perundang-undangan yang tak dapat dirampas oleh investor maupun Negara. Kehadiran PT. KJB dalam mengelola hutan Yamdena berdampak pada kepunahan pohon torem, dan merampas hak ulayat menyebabkan perlawanan masyarakat Tanimbar. 


\section{DAFTAR PUSTAKA}

Alaslan, Amtai (2021). Analilis Nilainilai Duan Lolat Berbasis Kearifan Lokal Pada Masayarakat Tanimbar di Kabupaten Maluku Tenggara Barat. Jurnal OTONOMI Vol. 11. No. 22

Faperta Unpatti, Fakultas Pertanian Universitas Pattimura Ambon, Laporan Studi Kelayakan Calon Areal Hak Pengusahaan Hutan PT. Inhutani I Pulau Yamdena Kabupaten Kepulauan Tanimbar, 1995.

http://www.harnas.co/2017/11/15/sejar ah- baru-bagi-pohon-torem, (10 Juli 2018).

Kajian Degradasi Hutan Di Pulau Yamdena, Maluku, 2009, http://storage.jakstik.ac.id/Produk Hukum/kehutanan/Kajian_Degrad asi_Yamdena_1998_2008.pdf,

Labetubun MS. Metode Pengaturan Hasil Hutan Tidak Seumur Melalui Pendekatan Model Dinamika Sistem (Kasus Hutan Alam Bekas Tebangan) [tesis]. Bogor: Sekolah Pascasarjana, Institut Pertanian Bogor, 2004.

Santosa, Andri (ed), Konservasi Indonesia: Sebuah Potret Pengelolaan dan Kebijakan, Cetakan ke-1, (Jakarta: Pokja Kebijakan Konservasi, USAID dan ESP, 2008).
Soerianegara I dan RHMJ Lemmens, (Ed)., Plant Resources of SouthEast Asia, No.51(1): Timber Tress: (Porsea Bogor: Major Commercial Timbers, 1994).

Keputusan Presiden No. 43 Tahun 1978 tentang Pengesahan Convention on International Trade of Endangered Species of Wild Fauna and Flora (CITES).

Undang-Undang Republik Indonesia Nomor 32 Tahun 2009 tentang Perlindungan dan Pengelolaan Lingkungan Hidup. 